\title{
The Principle of Evolving Capacities under the UN Convention on the Rights of the Child
}

\author{
Sheila Varadan \\ Leiden University, The Netherlands \\ s.r.varadan@umail.leidenuniv.nl
}

\begin{abstract}
The phrase "evolving capacities of the child" appears twice in the UNCRC, under articles 5 and 14(2) in the framework of parental guidance. Yet the term "evolving capacities" appears over 80 times in the General Comments of the CRC Committee. This paper examines the Committee's use of "evolving capacities" in its General Comments, suggesting that the term has been treated as an enabling principle, an interpretative principle, and a policy principle within the framework of the UNCRC. A broad principle of evolving capacities has thus emerged under the UNCRC that informs not only the framework of parental guidance, but the whole of the Convention. However, the CRC Committee does not recognise "evolving capacities" as a general principle or otherwise under the UNCRC. This paper examines why this might be, and concludes that more consideration needs to be given to the role of "evolving capacities" as a principle under the UNCRC.
\end{abstract}

\section{Keywords}

evolving capacities - article 5, CRC Committee - UN Convention on the Rights of the Child - capacities - agency

\section{1 \\ Introduction}

The idea that a child could exercise, claim and secure the enjoyment of rights independently under international law is still not entirely accepted. Historically, children have been defined by their vulnerability under international law, and afforded special treatment and protection on the basis of their relative

(C) SHEILA VARADAN, 2019 | DOI:10.1163/15718182-02702006

This is an open access article distributed under the terms of the prevailing CC-BY-NC license at the time of publication. 
physical and mental immaturity (UNCRC, preamble; Tobin, 2015). Concepts such as capacity and competency did not find expression in early child rights instruments (1924 Declaration, 1959 Declaration), and were notably absent from the first drafts of the UN Convention on the Rights of the Child ("UNCRC", "the Convention") (OHCHR, 2007, vol. 1). Parents were designated as the primary rights-holders in the care and upbringing of their children, and conferred with wide and unfettered authority under international law (article 18(4), ICCPR; article 13(3), ICESCR; article 26(3), UDHR). The family unit enjoyed a special status and protection under international law (articles 12 and 16(3), UDHR; article 10(1), ICESCR; articles 23(1) and 17, ICCPR), and the State generally did not interfere in the day-to-day parenting of children (Freeman, 1983). Childhood was viewed as a singular, fixed, and universal stage of life, for which 'the child's only remedy was to grow up' (Lansdown, 2005; Van Bueren, 1995; O'Neill, 1992: 32, 39); and, a child's lack of capacity was, at times, used as a basis to bring into question whether children could have rights at all (Brighouse, 2003: 45-6; Griffin, 2003, 27; O'Neill, 1992: 39).

So, when the phrase "evolving capacities of the child" appeared in the text of the UNCRC, it represented a distinct break from previously held conceptions of childhood and children under international law. It challenged the entrenched perception of the child as an object of protection, and introduced the prospect of the child as a rights-holder under international law. It created a direct relationship between the State and the child, rendering the child visible under international law (Lansdown, 2005: 6). Importantly, it recognised that as children grow and develop, their capacities evolve, and parents must adjust their direction and guidance to enable their children to exercise increasing agency over their lives. This was a somewhat radical departure from the traditional parent-child relationship, in which parents were the primary rights-holders and the child was a passive recipient of protection and care. It is likely for this reason that article 5 was described as an 'innovation' that remains 'unique in international law' (Kamchedzera, 2012: 6, 13) with "evolving capacities" characterised as 'a new principle of interpretation' in international law with 'profound implications for the human rights of the child' (Van Bueren, 1995: 51, 137; Lansdown, 2005: 3).

However, the significance of "evolving capacities" within the framework of the UNCRC remains unclear. It appears twice in the Convention, under articles 5 and 14(2), in the context of parental direction and guidance. Article 5 recognises the right of a child to receive appropriate direction and guidance from parents, legal guardians, extended family and community in a manner consistent with her evolving capacities in the exercise of rights under the UN Convention (article 5, UNCRC). Article 14(2), while mirroring the language of article 5, 
focuses on the child's right to freedom of thought, conscience and religion. In both contexts, the reference to "evolving capacities" does not so much create a right of the child to exercise rights in accordance with her evolving capacities as it recognises the right of children to receive appropriate guidance and direction from parents and guardians to secure the enjoyment of their rights in a manner consistent with their evolving capacities (Tobin and Varadan, 2019).

Yet, since the Convention's adoption in 1989, the term "evolving capacities" appears to have taken on a broader role. The UN Committee on the Rights of the Child ("Committee") references "evolving capacities" more than 80 times in 19 of its 23 General Comments. The issue of a child's evolving capacities has come up in at least 5 of the 22 Days of General Discussion, notably in the discussions on the Rights of Children and HIV/AIDS (1998), General Measures of Implementation (1999), Child Rights in Early Childhood (2004), the Right of the Child to be Heard (2006), and Digital Media and the Rights of the Child (2014). During the 2oth Anniversary of the UnCRC in 2009, the CRC Committee convened a panel discussion on "evolving capacities" as an emerging issue in the implementation of the UNCRC, encouraging its wider use in education programming, children's participation, protection frameworks and ageappropriate policies (2oth Anniversary Event, paras. 7, 23, 24(d), 43). In almost all of these instances, the Committee has engaged "evolving capacities" outside of the framework of article 5 and article 14(2).

What then is the role and function of "evolving capacities" within the framework of the UNCRC?

This paper seeks to answer this question by interrogating the Committee's use of "evolving capacities" in its commentary on the interpretation and implementation of the UNCRC. While it is acknowledged that the issue of children's capacity has been considered in the broader discourse on child rights, the ambition of this paper remains modest - to ascertain the role and function of "evolving capacities" as it is used and understood within the framework of the UNCRC. To do this, emphasis is placed on the work of the CRC Committee, specifically its General Comments. As the treaty-monitoring body of the UNCRC, the general comments of the CRC Committee act as authoritative statements on the implementation, interpretation and meaning of provisions under the UNCRC (CRC Committee, Rules of Procedure, 2015, Rule 77; Hanson and Lundy, 2017).

Part I examines the drafting history of the term "evolving capacities" within the UNCRC. Reviewing the reports of the CRC Working Group, this paper posits that it is unlikely that drafters intended to create a broad principle of "evolving capacities" under the UNCRC when they first coined the phrase in 
their discussions on the right to freedom of religion. The reports of the Working Group suggest that UNCRC drafters sought to forge a delicate balance within article 5 of the UNCRC, acknowledging the role of a child's evolving capacities, while still affirming the importance of parents and guardians in providing direction and guidance to their children.

Part II dissects the General Comments of the CRC Committee with a view to understanding how "evolving capacities" has come to be used by the Committee in its commentary. It is suggested that the CRC Committee has derived a role and function for "evolving capacities" that can be distilled into three broad categories: (1) "evolving capacities" as an enabling principle, in which the term is used to empower children's agency in the exercise of their rights under the UNCRC; (2) "evolving capacities" as an interpretative principle, in which the term is used to interpret specific provisions of the Convention in a manner that recognises children's capacities in the exercise of their rights; (3) "evolving capacities" as a policy principle, in which the term is used to guide States in policy-making and programming on children's rights. It is further suggested that the Committee's use of "evolving capacities" has introduced a role and function for the term that go well beyond the scope of article 5 of the UNCRC; and, in so doing, it has recognised a broader principle of evolving capacities under the UNCRC that not only informs the framework of parental direction and guidance, but the interpretation and implementation of the whole of the Convention.

Part III contemplates how such a principle of evolving capacities could be recognised within the framework of the UNCRC. It has been suggested that article 5 should be recognised as a general principle of the UNCRC to reflect the cross-cutting nature of "evolving capacities" under the UNCRC (Hanson and Lundy, 2017; Doek, 2007). However, this paper argues that recognising article 5 as a general principle would not necessarily result in "evolving capacities" being recognised as a broader principle or cross-cutting standard under the UNCRC. Article 5 recognises the child's right to receive appropriate direction and guidance from parents, legal guardians and other adult carers. It does not, on its face, enshrine a broader principle of evolving capacities under the UNCRC. On the contrary, it would appear from the discussions of the UNCRC Working Group that the intention was to delimit the scope of "evolving capacities" under article 5, carefully balancing it with the rights of parents and guardians (OHC HR, 2007, vol. 1). Thus, the principle of evolving capacities as it is used by the Committee today is broader than the scope of the term as it appears under article 5 .

A principle of evolving capacities potentially holds foundational value in the interpretation of the UNCRC: it is 'central to the balance embodied in the 
Convention between recognising children as active agents in their own lives, while also being entitled to protection in accordance with their relative immaturity and youth' (Lansdown, 2005: 3). Yet, this broad principle does not find expression in any single provision of the Convention nor has it been explicitly recognised by the Committee in its interpretation of the UNCRC. Recognising that every child is a subject of rights and, as such, entitled to increasing agency over the exercise of their rights as they evolve, has profound implications in how children are viewed, enabled and empowered within their families, communities, schools and society in general. This paper concludes that more consideration needs to be given to the role of "evolving capacities" as an overarching principle in the realisation of children's rights under the Convention.

\section{2 Part I - Drafting History of the "Evolving Capacities of the Child"}

The coinage of the phrase "evolving capacities of the child"' only came about half-way into the 11-year drafting process of the UNCRC, during the 1984 Working Group session (Working Group Report, 1984, para. 13; ОНCHR, 2007, vol. 1: 455 ). Until that point, the term had not emerged in the discussions of the CRC Working Group, and was notably absent from the text of the early drafts presented to the United Nations Office in Geneva by the Permanent Representative of Poland (OHCHR, 2007, vol. 1).

\subsection{Evolving Capacities and the Drafting of Article 14(2)}

The question of a child's evolving capacities first arose in the Working Group's discussions on freedom of thought, conscience and religion. Delegates raised concerns that children were not afforded enough consideration as rightsholders in the exercise of their right to freedom of religion, while parents and guardians continued to exercise almost unfettered authority over their children in their religious upbringing and education (Working Group Report, 1984, paras. 15-16; OHCHR, 2007, vol. 1: 455). To address these concerns, the delegation from Canada proposed a draft text for article 7 bis (article 14), introducing the phrase "evolving capacities of the child" (Working Group Report, 1984, paras. 15 - 16; O HCHR, 2007, vol. 1: 455). Previous instruments under international law, such as the Declaration on the Elimination of All Forms of Intolerance and of Discrimination Based on Religion or Belief (1981 Declaration) and the International Covenant on Civil and Political Rights (ICCPR), had not recognised the child's capacities in the exercise of their right to freedom of religion. In the ICCPR, States parties were only required 'to have respect for the liberty 
of parents ... to ensure the religious and moral education of their children in conformity with their own convictions' (ICCPR, 1966, article 18(4)): there was no mention of the child's rights or interests. Under the 1981 Declaration, the guiding principle was the best interests of the child, with parents retaining wide authority to choose the moral education for their children.

That a child's capacities can and should be recognised in the exercise of freedom of religion was a relatively new idea within the Working Group, and as such prompted some members to raise concerns that empowering a child in the exercise of their freedom of religion could undermine parental rights (Van Bueren, 1995). After a lengthy discussion on the proposed sub-paragraph, the delegations from the Netherlands and the Ukraine ssR suggested that a compromise text be drafted, and the delegation of the United Kingdom put forward a revised version (Working Group Report, 1984, para. 17). Following some amendments, the draft text was agreed:

The States Parties shall respect the rights and duties of the parents and, where applicable, legal guardians, to provide direction to the child in the exercise of his right in a manner consistent with the evolving capacities of the child. (OHCHR, 2007, vol. 1: 117)

This revised text was adopted in the first reading of the Working Group in 1984 (OHCHR, 2007, vol. 1: 117). However, debate re-ignited during the second reading. A new drafting group was established (composed of Bangladesh, China, the Holy See, Mexico Morocco, the Netherlands, and Poland and later joined by the United States of America, the Union of Soviet Socialist Republics, Argentina, Algeria, Egypt, Tunisia and two NGOs) (Working Group Report, 1989, paras. $280-281$ ). This new drafting group sought to introduce two new subparagraphs into the provision, one of which replicated article 18(4) of the ICCPR. The proposed text read as follows:

2. The States Parties shall equally respect the liberty of parents and when applicable, legal guardians, to ensure the religious and moral education of the child in conformity with their own conviction [of their choice].

3. Freedom to manifest one's religion or beliefs may be subject only to such limitations as are prescribed by law and are necessary to protect public safety, order, health, or morals or the fundamental rights and freedoms of others. (OHCHR, 2007, vol. 1: 463; Working Group Report, 1989, para. 280).

This drafting group reiterated concerns that any reference to a child's capacities would limit the scope of parental rights already established elsewhere under 
international law (article 18, ICCPR) (OHCHR, 2007, vol. 1; Working Group Report, 1989, para. 285; Van Bueren, 1995: 156-7). Delegations from Islamic states were not willing to accept any provision which potentially empowered children to change their religion or have choice over their religion (Van Bueren, 1995: 157). Other groups believed that it was in the best interests of the child that she adopt the religion of her father (Van Bueren, 1995: 157). In the end, in an attempt to achieve consensus, the Chairman of the Working Group removed the proposed new sub-paragraphs, claiming that this text was already replicated elsewhere in international law (онCHR, 2007, vol. 1: 464; Working Group Report, 1989, para. 288).

The issue, however, was far from resolved. Following the adoption of the UNCRC, the delegation of Holy See made a declaration that 'the right of parents to give their child a religious and moral education in conformity with their personal beliefs formed part of the right to manifest one's religion as per article 18(3) of the ICCPR' (Working Group Report, 1989, para. 290). Italy joined Holy See in its declaration (Working Group Report, 1989, para. 291). When the UNCRC entered into force in 1990, 21 States parties reserved on article $14^{1}$ of the UNCRC. This constituted the largest reservation on any single provision of the UNCRC.

\subsection{Evolving Capacities and the Drafting of Article 15 (Article 28)}

The issue of the child's evolving capacities re-surfaced in 1985 when the Working Group discussed article 15 (article 28) on the right of the child to education. The delegation from the Netherlands suggested that a sub-paragraph similar to article 14(2) be included under article 15 (article 28) (OHC HR, 2007, vol. 2: 642). According to the Netherlands, referencing "evolving capacities" was necessary to delimit the authority of parents under article 13(3) of the ICESCR, which allowed parents to 'choose for their children schools ... to ensure the religious and moral education of their children in conformity with their own convictions' (article 13(3), ICESCR). The proposal by the Netherlands was dropped from the final version of article 15 (article 28); however, the discussions on "evolving capacities" precipitated further conversations on the need for a general provision recognising the evolving capacities of the child within the text of the UNCRC.

1 Afghanistan, Algeria, Bangladesh, Brunei, Djibouti (withdrawn in 2009), Holy See, Indonesia, Iran, Iraq, Jordan, Kuwait, Malaysia, Maldives, Morocco, Oman, Pakistan, Qatar, Saudi Arabia, Somalia, Syria, and United Arab Emirates, accessed at: https://treaties.un.org/Pages/View Details.aspx?src=TREATY\&mtdsg_no=IV-11\&chapter=4\&clang=_en $(28$ September 2017). 


\subsection{Evolving Capacities and the Drafting of Article 5}

The pivotal discussion on "evolving capacities" came during the Working Group session in 1987 when delegates discussed but did not adopt article 7 ter relating to the civil and political rights of the child - freedom of expression, freedom of association and peaceful assembly, and right to privacy.

The delegation from Norway spoke of the 'need for a general provision dealing with the evolving capacities of the child' (Working Group Report, 1987, para. 115). Canada supported Norway and expressed a 'wish that the principle [of evolving capacities]... be dealt with in a comprehensive manner through a general article' (Working Group Report, 1987, para. 115). The representatives of Argentina and Sweden also voiced similar concerns, calling for a general provision recognising the evolving capacities of the child (Working Group Report, 1987 , paras. 115, 117).

During the 1987 Working Group session, a draft text was received from the delegations of United States and Australia for an article 5 bis. In that draft text, however, parents were emphasised as the primary rights holders with 'due regard for the importance of allowing the child to develop the skills and knowledge required for an independent adulthood' (Working Group Report, 1987, para. 100). The delegation from Canada was critical of the American draft text, stating that it would only support such a provision if there was 'due regard for the evolving capacities of the child and the child's need to mature into an independent adulthood' (Working Group Report, 1987, para. 104). Canada explained that the priority should be on protecting the child as a rights-holder, rather than reiterating parental rights:

... the family must not be given arbitrary control over the child. Any protection from the State given to the family must be equally balanced with the protection of the child within the family. (Working Group Report, 1987, para. 106).

The Chairman of the Working Group requested that a new proposal for article 5 bis be presented at the 1988 Working Group session (Working Group Report, 1987, para. 110). Australia, Austria, the Netherlands and the United States of America submitted the proposal for the draft text:

The States Parties to the present Convention shall respect the rights and duties of the parents and, where applicable, legal guardians, to provide direction to the child in the exercise of his or her rights enumerated in the present Convention in a manner consistent with the evolving 
capacities of the child, having due regard for the importance of promoting the development of the skills and knowledge required for an independent adulthood. (Working Group Report, 1988, para. 27).

The representatives of the Federal Republic of Germany expressed concern over the new draft text, arguing that parental rights would not be sufficiently safeguarded. The Germany delegation put forward its own draft text for a subparagraph under article 21 (article 41 of the UNCRC) of the draft Convention, which stated that, 'Nothing in this Convention shall affect the right and the duty of parents and, where applicable, legal guardians to take measures as are required for the upbringing and well-being of the child' (Working Group Report, 1988, para. 29).

The Working Group members responded to the proposal from Germany by highlighting that the Convention already recognised the critical role of parents in the upbringing of the child:

... If the emphasis was placed on the evolving capacities of the child in accordance with his age, the parents also had a role to play. Attention should be given to the growing child, and to his evolving capacities in a positive environment. The parents' rights in respect of bringing up the child were already well protected in article 8. (working group, 1988, para. 30).

The observer for Australia further noted that the role and function of a proposed article 5 bis was to interlink two important and general concepts:

[T] he proposed article would incorporate into the convention two important general concepts: (a) the evolving capacities of the child, and his or her rights as enumerated in the draft convention, and $(b)$ the rights and duties of the parents who raised the child, who provided guidance to and took primary responsibility for the child (emphasis added). (working Group Report 1988, para. 28 ).

While the representative from Germany eventually joined the consensus for the text of article 5 bis, he continued to suggest that an interpretational clause be attached to the UNCRC, which stated 'clearly that the draft convention was under no circumstances to be interpreted in a way that would affect the rights of parents or legal guardians' (Working Paper, 1988, para. 34). No such clause was ever attached to the UNCRC. 
The final version of article 5 bis was adopted following the second reading and now constitutes the text of article 5 of the UNCRC:

States Parties shall respect the responsibilities, rights, and duties of parents, or, where applicable, the members of the extended family or community as provided for by local custom, legal guardians or other persons legally responsible for the child, to provide, in a manner consistent with the evolving capacities of the child, appropriate direction and guidance in the exercise by the child of the rights recognized in the present Convention. (Working Group Report, 1987, para. 185).

The Working Group session reports, though not exhaustive, do offer some insight into the motivations and concerns that CRC drafters may have harboured when the phrase "evolving capacities of the child" was being discussed and penned into the texts of articles 5 and 14(2) of the UNCRC. It would appear that the foremost concern amongst Working Group members was that any explicit recognition of a child's capacities (evolving or otherwise) in the exercise of their rights would undermine the rights of parents and the sanctity of family. This was especially pronounced in discussions on freedom of religion, where many Working Group members viewed a child's exercise of freedom of religion as a direct threat to parental rights, and as potentially undermining the best interests of the child. That 21 States parties entered a reservation on article 14 - the highest number of reservations entered against any provision under the UNCRC - is a testament to these concerns.

At the same time, the fact that the issue of children's capacities would continue to re-emerge in the discussions of the Working Group, notably in the context of civil and political rights and the right to education, was not insignificant. It was during these discussions that a number of Working Group members identified the need for a general provision that would address the role of children's evolving capacities in the exercise of their rights under the UNCRC. To respond to these calls while still respecting the views of those Working Groups members who remained concerned about parental rights, the Committee sought to strike a delicate balance within article 5 . The wording of the provision would acknowledge the role of the evolving capacities of the child, while recognising the importance of parents, guardians, extended family and community in the upbringing of the child (OHCHR, 2007, vol. 1: 360; Working Group Report, 1988, paras. 30, 32; Tobin and Varadan, 2019). As such, the intended scope and function of article 5 was not to create a broad principle of evolving capacities under the Convention but to bring together two 
important general concepts within article 5 of the UNCRC: (a) the child as a rights holder under the UNCRC; (b) the rights, responsibilities and duties of parents and adult caregivers (legal guardians, community and extended family) in the upbringing of children under international law (Working Group Report, 1988 , para. 28 ).

\section{Part II - The CRC Committee's Use of "Evolving Capacities" in its General Comments}

In the three decades since the Convention's adoption, the term "evolving capacities" appears to have taken on a broader role and function outside of the framework of parental guidance and direction. It appears more than 80 times in 19 of the 23 General Comments (General Comment 1; General Comment 3; General Comment 4; General Comment 5; General Comment 7; General Comment 8; General Comment 9; General Comment 10; General Comment 11; General Comment 12; General Comment 13; General Comment 14; General Comment 15; General Comment 16; General Comment 17; Joint Recommendation No. 31 of the CEDAW Committee/General Comment No. 18, General Comment 20; General Comment 21; General Comment 22). The issue of a child's evolving capacities arose during 5 of the 22 Days of General Discussion, notably in discussions on the Rights of Children and HIV/AIDS (1998), General Measures of Implementation (1999), Child Rights in Early Childhood (2004), the Right of the Child to be Heard (2006), and Digital Media and the Rights of the Child (2014). During the 2oth anniversary of the Convention on the Rights of the Child in 2009, the CRC Committee convened a panel on "evolving capacities of the child as an enabling principle" in which it encouraged the wider application of the principle in education programming, children's participation, protection frameworks and age-appropriate policies (2oth Anniversary Event, paras. 7, 23, 24(d), 43).

It is suggested that the Committee has derived a role and function for "evolving capacities" that can be distilled into three broad categories: (1) "evolving capacities" as an enabling principle, in which the term is used to empower children in the exercise of their rights under the UNCRC; (2) "evolving capacities" as an interpretative principle, in which the term is used to interpret specific provisions of the Convention in a manner that recognises children's capacities in the exercise of their rights; (3) "evolving capacities" as a policy principle, in which the term is used to guide States in policy-making and programming on children's rights. 


\subsection{Evolving Capacities as an Enabling Principle}

As an enabling principle, "evolving capacities" serves four functions: (1) it affirms the child as a rights-holder under international law, recognising that as children grow, develop and mature, they acquire capacities to exercise increasing levels of agency over their rights; (2) it supports and recognises children's agency in decision-making; (3) it recognises that all children, even very young children, should be engaged as agents in the promotion and protection of their own rights (4) it crystalizes the role of parents and legal guardians as dutybearers to their children, providing guidance and direction to support their child's exercise and enjoyment of rights under the UNCRC.

The CRC Committee first recognized "evolving capacities" as an enabling principle in its General Comment No. 7, where it explained the role of a child's evolving capacities in the framework of parental guidance and direction:

Evolving capacities as an enabling principle. Article 5 draws on the concept of "evolving capacities" to refer to processes of maturation and learning whereby children progressively acquire knowledge, competencies and understanding, including acquiring understanding about their rights and about how they can best be realized. (General Comment No. 7, para 17).

The CRC Committee went on to elaborate the importance of a principle of evolving capacities in the realisation of children's rights:

Respecting young children's evolving capacities is crucial for the realization of their rights, and especially significant during early childhood, because of the rapid transformation in children's physical, cognitive, social and emotional functioning from earliest infancy to the beginnings of schooling. (General Comment No. 7, para. 17).

In its General Comment No. 20, the CRC Committee again invoked "evolving capacities" as an enabling principle, however this time, delinking it from the framework of parental guidance and direction:

The Committee defines evolving capacities as an enabling principle that addresses the process of maturation and learning through which children progressively acquire competencies, understanding and increasing levels of agency to take responsibility and exercise their rights. (General Comment No. 20, para. 18). 
In this first function, the Committee uses the principle of evolving capacities as a basis to recognise children's entitlement to exercise increasing agency over their rights as they grow and mature. It affirms that even very young children are rights-holders under the UNCRC, with an entitlement to progressive exercise of their rights as they grow, mature and develop. In other words, while a younger child requires more guidance in the exercise of rights, as a child grows and develops, there is a corresponding obligation to grant him or her increasing levels of agency to take responsibility over the exercise of rights.

In its second function, the Committee's use of "evolving capacities" as an enabling principle recognises the role of children's agency in decision-making. In General Comment No. 15, the Committee confirmed that "children's evolving capacities have a bearing on their independent decision-making in their health issues" (General Comment No. 15, para. 21); and in the context of young children, the Committee recognised that ' $[c]$ hildren, including young children, should be included in decision-making processes, in a manner consistent with their evolving capacities' (General Comment No. 12, para. 100).

At the same time, the Committee warned that enabling a child's evolving capacities should not 'obviate States' obligations to guarantee protection' (General Comment No. 20, para. 19):

In seeking to provide an appropriate balance between respect for the evolving capacities of adolescents and appropriate levels of protection, consideration should be given to a range of factors affecting decisionmaking, including the level of risk involved, the potential for exploitation, understanding of adolescent development, recognition that competence and understanding do not necessarily develop equally across all fields at the same pace and recognition of individual experience and capacity. (General Comment No. 20, para. 20).

So, while children continue to need appropriate levels of protection, there remains an obligation to enable children's agency in so far as their evolving capacities allow: 'By being guaranteed the right to be heard, to challenge rights violations and to seek redress, adolescents are enabled to exercise agency progressively in their own protection' (General Comment No. 20, para. 19). The Committee reaffirmed this point in the context of adolescents' right to health in General Comment No. 4: 'States parties have to take into account the evolving capacities of adolescents and involve them in an appropriate manner in developing measures, including programmes, designed to protect them' (General Comment No. 4, para. 12). 
In General Comment No. 3, the Committee further elaborated on the link between children's participatory rights and their agency in the exercise of rights: '[c]hildren are rights holders and have a right to participate in accordance with their evolving capacities in raising awareness by speaking out about the impact of HIV/AIDS on their lives and in the development of HIV/AIDS policies and programmes' (General Comment No. 3, para. 12). This point was reiterated in General Comment No. 5 where the Committee noted that '[c]hildren, including adolescents have the right to participate in raising awareness about their rights to the maximum extent of their evolving capacities' (General Comment No. 5, para. 69). In General Comment No. 12, the Committee emphasised that measures should be introduced to enable 'children to contribute their views and experiences to the planning and programming of services for their health and development' with the aim of promoting 'children's capacities to take increasing levels of responsibility for their own health and development' (General Comment No. 12, para. 104). And, again in General Comment No. 15, the Committee highlighted the link between children's right to be heard on 'all aspects of health provisions' and strengthening 'children's capacities to take increasing levels of responsibility for their own health and development' (General Comment No. 15, para. 19). Thus, in its third function, the principle of "evolving capacities" enables and strengthens children's participatory role in the promotion and protection of their own rights.

In its fourth function, "evolving capacities" as an enabling principle informs how parents and guardians should provide guidance and direction to their children under article 5 :

The Convention recognises the rights and responsibilities of parents, or other legal guardians, to provide appropriate direction and guidance to their children ... but underlines that this is to enable the child to exercise his or her rights and requires that direction and guidance are undertaken in a manner consistent with the evolving capacities of the child (emphasis added). (General Comment No. 12, para. 91).

The Committee explains that:

Evolving capacities should be seen as a positive and enabling process, not an excuse for authoritarian practices that restrict children's autonomy and self-expression ... Parents (and others) should be encouraged to offer "direction and guidance" in a child-centred way through dialogue and 
example, in ways that enhance young children's capacities to exercise their rights .... (General Comment No. 7, para. 17).

The Committee expounded on this point further in its General Comment No. 12:

The more the child himself or herself knows, has experience and understands, the more the parent, legal guardian or other persons legally responsible for the child have to transform direction and guidance into reminders and advice and later to an exchange on an equal footing. This transformation will not take place at a fixed point in a child's development, but will steadily increase as the child is encouraged to contribute her or his views. (General Comment No. 12, para. 84).

In this fourth function, the Committee makes clear that parents and guardians no longer carry a carte blanche in how they provide guidance and direction to their children: parental guidance and direction must be provided in a manner that reflects a child's unique needs and evolving capacities, and such guidance needs to be adjusted continually to enable the child to exercise progressive levels of agency and responsibility in the exercise of her rights. Viewed in this way, "evolving capacities" as an enabling principle has 'profound significance for the triangular relationship between the child, the family and the State' (Lansdown, 2005: ix): it transforms the role of the parent from primary rights-holder over their child, to duty-bearer to their child in the child's exercise of her rights under the UNCRC.

\subsection{Evolving Capacities as an Interpretative Principle}

The Committee has invoked "evolving capacities" in its interpretation of at least 14 provisions under the UNCRC. This section examines the role and function of "evolving capacities" as an interpretative principle in respect of the following provisions under the UNCRC: (1) General Principles - article 2 (Non-discrimination), article 3 (Best interests of the child), article 6 (Survival and development) through the framework of article 29 (Education rights) and article 31 (Right to play), and article 12 (Right to be heard); (2) Civil and Political Rights - article 13 (Freedom of expression), article 14 (Freedom of thought, conscience and religion), and article 17 (Access to information); (3) Reading-in of "evolving capacities" - article 8 (Preservation of identity), article 16 (Right to privacy), article 18 (Parental responsibilities), article 27 (Adequate standard of living), and article 24 (Right to health). 
3.2.1 Evolving Capacities and the General Principles of the UNCRC

3.2.1.1 Article 2-The Child's Evolving Capacities as a Basis for

\section{Discrimination}

Although the Committee does not specifically reference "evolving capacities" in its interpretation of article 2, it does recognise that a child's capacities, or perceived lack thereof, can be a basis for discrimination when children are denied or restricted access to rights under the UNCRC. In its General Comment No. 20, the Committee observed that '[a]dolescence itself can be a source of discrimination' (General Comment No. 20, para. 21), explaining that adolescents are 'often treated as incompetent and incapable of making decisions about their lives' (General Comment No. 20, para. 21). In its General Comment No. 4, the Committee called on States to ensure that minimum ages were '... the same for boys and girls (article 2 of the Convention) and closely reflect the recognition of the status of human beings under 18 years of age as rights holders, in accordance with their evolving capacity, age and maturity ...' (General Comment No. 4, para. 9). The Committee emphasised that unequal access to information, commodities and services related to sexual and reproductive health 'amounts to discrimination' (General Comment No. 20, para. 59). Thus, while "evolving capacities" is not directly cited in the interpretation of article 2 , the principle nonetheless plays a role in the interpretation of non-discrimination, ensuring that a child's capacities, or perceived lack thereof is not used as a basis to deny or restrict access to rights under the UNCRC.

\subsubsection{Article 3-The Role of Evolving Capacities in the Determination of the Best Interests of the Child}

The Committee drew an important link between the evolving capacities of the child and the best interest of the child in its General Comment on article 3(1). It recognised that as a child's capacities evolve, increasing weight should be accorded to his or her views in the determination of best interests. The Committee emphasised that ' $\mathrm{t}$ ] he evolving capacities of the child (art. 5) must be taken into consideration when the child's best interests and right to be heard are at stake' (General Comment No. 14, para. 44), explaining that '...as the child matures, his or her views shall have increasing weight in the assessment of his or her best interests' (General Comment No. 14, para. 44; General Comment No. 20, para. 22). The Committee reiterated this point in its General Comment No. 20: 'when determining best interests, the child's views should be taken into account, consistent with their evolving capacities ...' (General Comment No. 20, para. 22). So, while the best interests of the child remains the primary consideration (article $3(1)$ ), the right to be heard 'provides the methodology for 
hearing the views of the child' (General Comment No. 14, para. 43), and the principle of evolving capacities serves as the framework in which to recognise and attribute weight to a child's agency in the best interests' determination. Thus, as an interpretative principle "evolving capacities" plays an important role in maintaining the balance embodied in the Convention between 'recognising children as active agents in their own lives, entitled to be listened to, respected and granted increasing autonomy in the exercise of rights' while still ensuring each child the unique protection they need, in accordance with their relative immaturity and youth (Lansdown, 2005:3).

\subsubsection{Article 6-Evolving Capacities in the Interpretation of the Child's Right to Survival and Development}

The CRC Committee has not engaged in an extended discussion on the role of "evolving capacities" in the interpretation of the right to survival and development. However, the Committee did link "evolving capacities" with the child's development in its General Comments on articles 12, 29 and 31. The Committee recognised that enabling a child to engage rights (such as the right to be heard) stimulated development, and thus contributed to the realisation of the right to development under article 6. In General Comment No. 12, the Committee explained that:

[C]hild participation is a tool to stimulate the full development of the personality and the evolving capacities of the child consistent with article 6 and with aims of education embodied in article 29 (emphasis added). (General Comment No. 12, para. 79).

The Committee drew a similar link in the context of education, identifying the key goal of education as the 'development of the individual child's personality, talents and abilities', and calling for educational curricula to be 'of direct relevance to the child's social, cultural, environmental and economic context and to ... take full account of the child's evolving capacities' (General Comment No. 1, para. 9).

In the framework of the right to play, the CRC Committee referenced children's development alongside "evolving capacities" in its interpretation of article 31:

States parties must ensure, to the maximum extent possible, the life, survival and development of the child. In this regard, the Committee draws attention to the need to recognise the positive value of each dimension of article 31 in promoting the development and evolving capacities of the children (emphasis added). (General Comment No. 17, para. 18). 
Interestingly, in its General Comment No. 20, the Committee referenced '[r]espect for evolving capacities' as part of the 'Right to development' in its section on the 'General principles of the Convention' (General Comment No. 20 , paras. 14, 18, 19, 20). While article 6 was not explicitly mentioned in General Comment No. 20, it would appear that the Committee drew an implicit link between "evolving capacities" and development, noting that the "implementation of rights should take account of children's development and their evolving capacities' (General Comment No. 20, para. 1).

\subsubsection{Article 12 - Evolving Capacities in the Interpretation of the Right to be Heard}

The Committee's most extensive discussion on the interpretative role of "evolving capacities" comes in its commentary on article 12 (right to be heard). The Committee ascribes three functions to "evolving capacities" in its interpretation of article 12: (1) interpreting 'capable of forming his or her own views' in a manner that enables all children to engage their rights under article 12; (2) providing a framework for assessing and attributing 'due weight' to the views of the child; (3) recognising the right to be heard as a condition precedent in the child's right to receive appropriate direction and guidance from parents, guardians and adult carers under article 5 .

In its first function, the CRC Committee invokes the concept of evolving capacities to dispel the notion that a child must meet a threshold of competency to be 'capable of forming his or her own views' under article 12 of the UNCRC. The Committee explains that the reference to 'capable of forming his or her own views' 'should not be seen as a limitation, but rather as an obligation for States parties to assess the capacity of the child to form an autonomous opinion to the greatest extent possible' (General Comment No. 12, para. 20) and to create an environment to enable the child to express her views. The Committee explains that States 'cannot begin with the assumption that a child is incapable of expressing his or her own views' but instead must 'presume that a child has the capacity to form her or his own views and recognise that she or he has the right to express them' (General Comment No. 12, para. 20). The Committee stresses that 'article 12 imposes no age limit on the right of the child to express her or his views and discourages States parties from introducing age limits either in law or in practice which would restrict the child's right to be heard in all matters affecting her or him' (General Comment No. 12, para. 21). In other words, 'it is not up to the child to first prove her or his capacity' (General Comment No. 12, para. 20). In its Day of General Discussion on child rights in early childhood, the Committee 'underlined the concept of the child as rights holder' who 'is able to form views from the youngest age, even when she or he may be unable to express them verbally' (General Comment No. 12, para. 21). 
Thus, the obligation falls on the State party to enable children to express their views, and ' $[\mathrm{c}]$ onsideration needs to be given to the fact that children will need differing levels of support and forms of involvement according to their age and evolving capacities' (General Comment No. 12, para. 134(e)).

In its second function, the CRC Committee introduces the prospect of using "evolving capacities" as a framework to accord "due weight" to the views of the child under article 12 of the UNCRC. The CRC Committee has stated that ' $[\mathrm{c}]$ onsideration needs to be given to the notion of the evolving capacities of the child' (General Comment No. 12, para. 31) explaining that 'article 12 makes it clear that age alone cannot determine the significance of a child's view. Children's level of understanding is not uniformly linked to their biological age' (General Comment No. 12, para. 29). In at least two instances, the CRC Committee uses "evolving capacities" as a basis to assess "due weight". In the context of children with disabilities, the CRC Committee notes that the child's views need to be respected in accordance with their evolving capacities (General Comment No. 9, para. 32), while in the context of migration, the CRC Committee places "evolving capacities" alongside "age and maturity" (General Comment No. 22, para. 34).

While there remains considerable scope for the Committee to elaborate on the role of "evolving capacities" in the assessment of "due weight", it is nonetheless important to note that the Committee has looked to "evolving capacities" as a framework in its interpretation of article 12.

In its third function, the Committee embeds article 12 within article 5 , introducing something akin to a condition precedent on parents and adult caregivers providing direction and guidance to their children:

... the child has a right to direction and guidance, which have to compensate for the lack of knowledge, experience and understanding of the child and are restricted by his or her evolving capacities .... (General Comment No. 12, para. 84).

This requirement is stimulated by article 12 of the Convention, which stipulates that the child's views must be given due weight, whenever the child is capable of forming her or his own views ... as children acquire capacities, so they are entitled to an increasing level of responsibility for the regulation of matters affecting them. (General Comment No. 12, para. 85).

In other words, for parents and guardians to provide appropriate direction and guidance to children in line with article 5 , they must take into account the 
views of children, and as a child's capacities evolve, greater weight must be ascribed to the views of the child, with parents and guardians adjusting their guidance and direction to reflect the child's evolving capacities in the exercise of her or his rights.

\section{2 .2}

Evolving Capacities and Civil and Political Rights under the UNCRC

The use of "evolving capacities" in the interpretation of civil and political rights serves two functions: (1) it affirms the child's status as the primary rights-holder and agent in the exercise of civil and political rights; (2) it recognises the States' obligation to create environments that enable and empower children to exercise their civil and political rights, in accordance with their evolving capacities. In its commentary on article 14, the Committee confirmed that, it is the child who exercises the right to freedom of religion, not the parent, and the parental role necessarily diminishes as the child acquires an increasingly active role in exercising choice throughout adolescence' (General Comment No. 20, para. 43). The Committee reiterated this point in the same General Comment with respect to article 13, 'the obligation of parents and caregivers to provide appropriate guidance in accordance with the evolving capacities of adolescents should not interfere with adolescents' right to freedom of expression (General Comment No. 20, para. 42).

In its second function, the Committee recognises an obligation on States to create environments that enable and empower children in the exercise of their civil and political rights, taking into account the principle of evolving capacities. In respect of article 14, the Committee called on States to ensure that a child's freedom of religion is 'respected in schools and other institutions, including with regard to choice over attendance in religious instruction classes' (General Comment No. 20, para. 43); and in respect of article 17 (Freedom of association), the Committee noted that it fell on the State to 'guarantee that adolescents' right to freedom of association and peaceful assembly in all its forms is fully respected ... including through the provision of safe spaces for both girls and boys' (General Comment No. 20, para. 45). It is in this latter function that one sees "evolving capacities" stretched beyond the framework of parental guidance and direction.

\subsubsection{Reading-in of Evolving Capacities under the UNCRC}

In a number of other instances, the CRC Committee simply reads-in "evolving capacities" without further explanation. For instance, in its interpretation of article 8 (Right to identity), the Committee states that "[a]lthough children and young people share basicuniversalneeds, the expression of those needs depends 
on a wide range of personal, physical, social and cultural aspects, including their evolving capacities' (General Comment No. 14, para. 55). In its interpretation of article 16 (Right to privacy), the Committee specifies that 'States should ... take all appropriate measures to strengthen and ensure respect for the confidentiality of data and the privacy of adolescents, consistent with their evolving capacities' (General Comment No. 2o, para. 46). In interpreting articles 18 and 27 (Adequate standard of living), the Committee notes that:

States parties have a positive and active obligation to support and assist parents and other caregivers to secure, within their abilities and financial capacities and with respect for the evolving capacities of the child, the living conditions necessary for the child's optimal development. (General Comment No. 13, para. 5; General Comment No. 21, para. 15).

Reading-in "evolving capacities", without any further explanation or reference to article 5 , reveals a seemingly settled practice by the Committee of treating "evolving capacities" as a broader principle within the framework of the UNCRC.

\subsection{Evolving Capacities as a Policy Principle}

The Committee has relied on "evolving capacities" as a policy principle across a range of issues, such as children's education, HIV/AIDS, adolescent health, early childhood development, corporal punishment, violence against children, harmful practices, children's health, rest and play, indigenous children's rights and adolescents' rights. As a policy principle, "evolving capacities" serves two functions: (1) it improves children's access to rights and strengthens their role as decision-makers in the exercise of their rights; (2) it guides minimum age laws. In both functions, "evolving capacities" is delinked from the framework of parental guidance and direction.

In its first function, the Committee uses "evolving capacities" to encourage States to improve adolescents' access to health services: due attention must be given to the evolving capacities of the child to ensure the accessibility of voluntary, confidential HIV counselling and testing services (General Comment No. 3, para. 22). In the context of HIV-related research, the Committee relies on "evolving capacities" as a basis to recognize children's agency in decision-making: '[i]n line with the child's evolving capacities, consent of the child should be sought' in HIV/AIDs biomedical research, HIV/AIDS operations, and social, cultural and behavioural research (General Comment No. 3, para. 29). 
In the context of education, the Committee relies on "evolving capacities" to guide education policies to create " $[\mathrm{s}] \mathrm{chools}$ [that] foster a humane atmosphere and allow children to develop according to their evolving capacities' (General Comment No. 1, para. 12).

In its second function, the Committee relies on "evolving capacities" to inform minimum age laws in sexual consent, marriage and the possibility of medical treatment without parental consent (General Comment No. 4, para. 9). The Committee has said that 'minimum ages should ... closely reflect the recognition of the status of human beings under 18 years of age as rights holders, in accordance with their evolving capacity, age and maturity (arts. 5 and 12 to 17)' (General Comment No. 4, para. 9). In at least one instance, the Committee references "evolving capacities" as a possible basis for setting a minimum age, '... [s] uch laws or regulations should stipulate an age for this process, or refer to the evolving capacity of the child...' (General Comment No. 4, para. 33). In its General Comment No. 18 on harmful practices, the CRC Committee invokes "evolving capacities" as a basis to justify marriages of children below the age of 18 years: '[a]s a matter of respecting the child's evolving capacities and autonomy in making decisions that affect her or his life, a marriage of a mature, capable child below 18 years of age may be allowed in exceptional circumstances ...' (General Comment No. 18, para. 20).

In other instances, the Committee has invoked "evolving capacities" as an enabling principle to guide policy more generally. As already noted above, the CRC Committee held an event on the 2oth anniversary of the Convention on the Rights of the Child, during which it convened a panel on "evolving capacities" as an enabling principle in practice. In its recommendations, the Committee appeared to recognise the increasing significance of the principle of evolving capacities under the Convention:

States parties should elaborate on the consequences of the recognition of the child as a person with evolving capacities to exercise her or his own rights and consider the establishment of appropriate ages for the independent exercise of some rights, allowing for flexible application. This would recognize the capacities of the child while providing necessary protection to the child and clear standards for those who have to implement and respect the rights of the child (2oth Anniversary Event, recommendation 5 ).

The Committee has further shown a willingness to recognise "evolving capacities" as part of a broader policy framework under General Comments Nos. 13 
and 21. In General Comment No. 13, the Committee introduced the child rights approach as a policy framework:

Definition of a child rights approach. Respect for the dignity, life, survival, well-being, health, development, participation and non-discrimination of the child as a rights-bearing person should be established and championed as the pre-eminent goal of States parties' policies concerning children ... It requires a paradigm shift away from child protection approaches in which children are perceived and treated as "objects" in need of assistance rather than as rights holders entitled to non-negotiable rights to protection. A child rights approach is one which furthers the realization of the rights of all children as set out in the Convention by developing the capacity of duty-bearers to meet their obligations to respect, protect and fulfil rights (art. 4) and the capacity of rights holders to claim their rights ...' (emphasis added). (General Comment No. 13, para. 59).

The Committee went on to explain that:

This approach is based on the declaration of the child as a rights holder and not a beneficiary of benevolent activities of adults. It includes respecting and encouraging consultation and cooperation with, and the agency of, children in the design, implementation, monitoring and evaluation of the coordinating framework and specific measures therein, taking account of the age and evolving capacities of the child or children (emphasis added). (General Comment No. 13, para. 72(a)).

The Committee expounds on the child rights approach in its General Comment No. 21, stating that 'the process of realising children's rights is as important as the end result. A child rights approach ensures respect for the dignity, life, survival, well-being, health, development, participation and nondiscrimination of the child as a rights holder' (General Comment No. 21, para. 10): it draws on 'child rights standards and principles from the Convention and other international human rights instruments to guide behaviour, actions, policies and programmes' with the aim of building 'the capacity of children as rights holders to claim their rights and the capacity of duty bearers to fulfil their obligations to children' (General Comment No. 21, para. 11(b), 11(c)).

Thus, the Committee's use of "evolving capacities" in the policy context suggests a role and function for the term that extends beyond the scope of parental guidance and direction under article 5 and article 14(2), introducing a framework to guide States in their programming on children's rights. 


\subsection{A Principle of Evolving Capacities under the UNCRC}

Studying the CRC General Comments, it would appear that the Committee's use of "evolving capacities" has stretched the term well beyond the framework of parental guidance where it was first conceived of under articles 5 and 14(2). In so doing, it would appear that the Committee has introduced a broader principle of evolving capacities under the UNCRC that not only informs the framework of parental direction and guidance but the interpretation and implementation of the Convention as a whole.

As an enabling principle, "evolving capacities" acknowledges the processes of maturation and learning that all children undergo, recognising that as a child grows, develops and matures, he or she becomes entitled to increasing levels of agency and responsibility over the exercise of rights (General Comment No. 7, para. 17; General Comment No. 20). The Committee's use of “evolving capacities" as an enabling principle serves four functions: (1) it affirms that all children, even very young children are rights-holders under the UNCRC; (2) it recognizes the role of children's agency in decision-making; (3) it introduces an obligation on States to engage children in the promotion and protection of their rights, in so far as their evolving capacities permit; (4) it crystalizes the role of parents and legal guardians as duty-bearers to their children in the child's exercise of their rights under the UNCRC. In short, it changes how children are perceived, enabled and empowered in the exercise and enjoyment of their rights under international law.

As an interpretative principle, "evolving capacities" introduces a framework in which provisions of the Convention are interpreted in a manner that supports the child's exercise of rights in line with their evolving capacities. It also introduces an obligation on States, alongside parents and guardians, to take measures to support children in the exercise of their rights as their capacities develop, creating environments adapted to their evolving capacities, and ensuring they are provided with the resources and information needed to exercise their rights in institutional settings.

As a policy principle, "evolving capacities" unshackles States from traditional policy-making frameworks, in which children are presumed to lack capacity until they cross a specific age-barrier or reach a prescribed age of adulthood. It debunks the notion that children must reach a requisite threshold of capacity to be able to exercise their rights; and it recognises that as children grow and develop, they need to be progressively enabled and empowered in the exercise of their rights. It challenges perceptions of capacity as a binary concept, replacing it with a framework that views it as dynamic and fluid process, recognising the 'wide range of qualities - moral, social, cognitive, physical and emotional' - that encompass capacity (Lansdown, 2005: 23). It further 
recognises that 'children, like adults, will not acquire a consistent and overall level of capacity across all fields' according to a fixed and uniform process and 'expressions of competence will vary according to the nature of the tasks involved, their personal experiences, expectations placed on them, social context and individual abilities' (Lansdown, 2005: 23).

Taken together, the Committee's use of "evolving capacities" introduces a role and function for the term that has a far-reaching and transformative impact on how children are viewed, enabled, and empowered within their families, schools, communities and society generally. The Committee's use of "evolving capacities" is thus much wider and more radical than what was likely envisaged by the UNCRC Working Group when it first penned the phrase into the texts of articles 5 and 14(2) of the Convention.

Part III - Evolving a Place for the Principle of Evolving Capacities under the UNCRC

Interestingly, the Committee does not recognise "evolving capacities" as a general principle under the UNCRC. Indeed, when the Committee met for the first time in 1991 and identified the four general principles of the Convention - nondiscrimination (article 2), best interests of the child (article 3(1)), the right to development (article 6), and the right to be heard (article 12) - the evolving capacities of the child did not feature in the discussions (Hanson and Lundy, 2017; Goodman, 1992).

However, there have been consistent calls over the years to recognise article 5 as a general principle under the Convention. Even in the final stages of the UNCRC drafting, it was suggested by UNICEF that article 5 be recognised as a general provision of the Convention on the basis that it featured amongst the first provisions (Hanson and Lundy, 2017: 288; онCHR, 2007, vol. 1: 6). Doek (2007) and Detrick (1999) have separately suggested that article 4 and article 5 be included as general principles of the UNCRC on the basis that both provisions introduce general obligations applicable to the whole of the UNCRC. In their recent analysis, Hanson and Lundy called for a re-evaluation of the composition and nomenclature of the general principles, proposing that article 6 be replaced with article 5, and the label "general principles" be discarded in favour of two categories - "overall implementing obligations" and "crosscutting standards"' of the UNCRC. Hanson and Lundy suggested that article 5 be recognised as a cross-cutting standard under the UNCRC, given that "evolving capacities" has become a concept 'widely used by many child rights actors in a cross-cutting role' (Hanson and Lundy, 2017: 301, 302). 
However, elevating article 5 to the status of a general principle (or crosscutting standard) would not necessarily recognise "evolving capacities" in the manner that it has come to be understood by the Committee in its General Comments. A plain reading of article 5 does not support an interpretation of "evolving capacities" as a broader principle as used by the Committee in its General Comments. The reference to evolving capacities of the child as it appears under article 5 is meant to inform the manner in which children receive appropriate guidance and direction - not to enshrine a broader principle under the UNCRC. This is corroborated in the discussions of the CRC Working Group, many of whom saw article 5 as reflecting a 'delicate balance' between children as rights-holders and the correlative rights of parents (OHCHR, 2007, vol. 1: 360 ), and the interlinking of two important general concepts under the Convention (OHCR, 2007, vol. 1: 360).

This is further corroborated in the Committee's own treatment of "evolving capacities" in its General Comments. For the most part, the Committee delinks its references to "evolving capacities" from article 5 and parental guidance and direction. In the over 80 references to "evolving capacities", article 5 is referenced in only 14 instances across 7 General Comments (General Comment No. 4; General Comment No. 11; General Comment No. 12; General Comment No. 13; General Comment No. 14; General Comment No. 20; General Comment No. 21). In other words, in the vast majority of instances, the Committee invokes the principle of evolving capacities delinked from article 5 and the framework of parental guidance under the UNCRC. A few notable examples are provided below to demonstrate this point.

In its commentary on HIV/AIDS and the rights of children in General Comment No. 3, the Committee refers to "evolving capacities" eight times, invoking it as an enabling principle, an interpretative principle and a policy principle, yet it never refers to article 5 or the framework of parental guidance and direction (General Comment No. 3, paras. 12, 20, 22, 23, 29, 40(f)). In General Comment No. 1 on the aims of education, the Committee references "evolving capacities" three times, again with no reference to article 5 or parental guidance and direction (General Comment No. 1, paras. 1, 9, 12). In General Comment No. 15 on the child's right to health, the Committee invokes "evolving capacities" six times as an enabling principle and a policy principle, and again with no reference to article 5 or parental guidance and direction (General Comment No. 15 , paras. 21, 22, 31, 78). In its General Comment No. 5 on the implementation of the Convention, the Committee cites "evolving capacities" in its reference to States' obligations under article 42, again delinking it from article 5 and the framework of parental guidance and direction (General Comment No. 5, para. 69). In its General Comment No. 18 on harmful practices, the Committee 
relies on "evolving capacities" to recognise exceptional circumstances in which a child can marry under 18 years of age (General Comment No. 18, para. 20), and again there is no reference to parental guidance or article 5 .

To recognise article 5 as a general principle of the UNCRC, without due consideration given to the manner in which "evolving capacities" has come to be used and understood by the Committee would likely obfuscate the scope and function of article 5 , while not actually resolving the need to recognise the principle of evolving capacities more broadly under the UNCRC. How then should a principle of evolving capacities be recognised and understood under the Convention? It is suggested that a different avenue, outside of the framework of article 5, will likely need to be found, in order to recognise the overarching principle of evolving capacities under the Convention. The Committee has already shown its willingness to treat "evolving capacities" as a broader principle within the framework of the UNCRC. What is needed now is formal recognition of this principle in a manner that aligns with the Committee's use and understanding of the term in its General Comments. Whether labelled as a "guiding principle", "umbrella principle" or "crosscutting standard", the nomenclature applied to "evolving capacities" must reflect its stature as a broader principle, delinked from articles 5 and 14(2), and its overarching role in the interpretation and implementation of the whole of the Convention.

\section{Conclusion}

A child's capacity, or perceived lack thereof, will undoubtably play a role in how she is able to secure the enjoyment of rights under international law. Children have historically been defined by their vulnerability, and generally presumed to be incompetent under the law. However, the work of Alderson amongst others, has convincingly shown that even at a very young age, children are able to express agency and autonomy over their lives, and are often capable of decision-making much earlier than the legally prescribed age of competency (Alderson, 1990; Alderson, 1993; Alderson, 1996). Yet, the capacity of children continues to be undervalued and overlooked in all areas of life (Freeman, 2007: 13; Tobin, 2013: 201).

When the delegates of the UNCRC Working Group first coined the phrase "evolving capacities of the child" in 1984, it is unlikely they intended for it to be interpreted beyond the immediate concern of establishing a counter-balance to the wide liberties afforded to parents under international law in respect of 
their child's right to freedom of religion. However, when the notion of children's evolving capacities continued to re-emerge in the CRC drafting process, a different discussion ensued - was there need for a general principle of evolving capacities under the UNCRC?

The Working Group was unable to definitively resolve this issue at the time of the drafting of the CRC. However, in the almost three decades since the Convention entered into force, the CRC Committee appears to have answered this question by introducing a broad principle of evolving capacities under the UNCRC. The Committee has invoked "evolving capacities" over 80 times in 19 of its 23 General Comments, and referenced it across a variety of contexts elsewhere. The term "evolving capacities" has taken on broad role and function as an enabling principle, as an interpretative principle, and as a policy principle within the UNCRC. What is needed now is an explicit acknowledgment from the Committee of the principle of evolving capacities within the framework of the UNCRC. Without such recognition, the principle of evolving capacities with its potential to transform how we view, enable and empower children's agency in the realisation of their rights will continue to go unnoticed, and the promise of a paradigm shift in which the child is no longer viewed as an object of protection, but as a subject of rights under international law will remain largely theoretical.

To borrow from an analogy suggested by UNICEF: the process of realising children's rights can be likened to a table (UNICEF, 2014: 24-25). The four legs of the table represent the key provisions needed to realise children's rights under the UNCRC: non-discrimination (article 2), best interests of the child (article 3(1)), parental guidance and direction (article 5), and the right to be heard (article 12). The table top represents the child's survival and development (article 6), and the rug on which the table stands represents the implementation of children's rights (article 4). What is missing from this image is a chair that would enable the child to sit on her own at the table. The principle of evolving capacities represents that missing chair within the framework of the UNCRC: it secures for every child the prospect of claiming, exercising and enjoying their rights independently under international law.

\section{Acknowledgement}

The author wishes to thank Jaap Doek, Ton Liefaard and John Tobin for their helpful comments and kind words of encouragement. 


\section{References}

\section{Books and Chapters}

Abramson, B., "Article 2. The Right of Non-Discrimination" in Alen A., Vande Lanotte J., Verhellen E., Ang F., Berghmans E., and Verheyde M (eds.), A Commentary on the United Nations Convention on the Rights of the Child (Leiden: Martinus Nijhoff Publishers, 2008).

Alderson, P., Choosing for Children: Parents' Consent to Surgery (Oxford University Press: United Kingdom, 1990).

Alderson, P., Children's Consent to Surgery (Open University Press: United Kingdom, 1993).

Alderson, P. and Montgomery, J., Health Care Choice: Making Decisions with Children (Participation \& consent) (Institute of Public Policy: United Kingdom, 1996).

Brighouse, H., "What Rights (If Any) Do Children Have?" in D. Archard and C.M. Macleod (eds.), The Moral and Political Status of Children (Oxford: Oxford University Press, 2003).

Doek, J., "The CRC General Principles" in 18 Candles: The Convention on the Rights of the Child Reaches Majority (Geneva: Institut international des droits de l'enfant, 2007), 31-42.

Detrick, S., A Commentary on the United Nations Convention on the Rights of the Child (The Hague: Martinus Nijhoff Publishers, 1999).

Freeman, M.D.A., The Rights and Wrongs of Children (Dover, New Hampshire: Frances Pinter, 1983).

Griffin, J., "Do Children Have Rights?" in D. Archard and C.M. Macleod (eds.), The Moral and Political Status of Children (Oxford: Oxford University Press, 2003).

Kamchedzera, Garton, "Article 5. The child's right to appropriate direction and guidance" in A Alen., J. Vande Lotte, E. Verhellen, F. Ang, E. Berghmans, and M. Verheyde (eds.), A Commentary on the United Nations Convention on the Rights of the Child (Leiden: Martinus Nijhoff Publishers, 2012).

Lansdown, G., The Evolving Capacities of the Child (Florence: UNICEF Innocenti, 2005).

Tobin, J., and Varadan, S., "Article 5: The Right to Parental Direction and Guidance and Consistent with a Child's Evolving Capacities" in Tobin, J. and Alston, P. (eds.), The UN Convention on the Rights of the Child: A Commentary (Oxford: Oxford University Press, forthcoming March, 2019).

UNICEF, Child Rights Education Toolkit: Rooting Child Rights in Early Childhood Education, Primary and Secondary Schools, 1st ed. (Geneva: UNICEF, 2014).

Van Bueren, G., The International Law on the Rights of the Child (Dordrecht: Martin Nijhoff Publishers, 1995). 


\section{Peer-reviewed Journal Articles}

Alderson, P., “Giving Children's Views 'Due Weight' in Medical Law”, International Journal of Children's Rights 2018 (26) 16-37. DOI: 10.1163/15718182-0201001.

Alston, P., "The Legal Framework of the Convention on the Rights of the Child" in United Nations Bulletin of Human Rights: The Rights of the Child (91(2)) United Nations Geneva, 1992.

Archard, D., “Do Parents own their children?", International Journal of Children's Rights $1993(1(3)) 293-301$.

Eekelaar, J., “The Emergence of Children's Rights” (1986), 6 Oxford Journal of Legal Studies 2, 161-182.

Eekelaar, J., "The Interests of the Child and the Child's Wishes: The Role of Dynamic Self-Determinism" (1994), 8 International Journal of Law and the Family 42-61.

Freeman, M.D.A., "Taking Children's Rights More Seriously”, International Journal of Law and the Family 1992 (6(1)) 52-71.

Freeman, M.D.A., "Why It Remains Important to Take Children's Rights Seriously", International Journal of Children's Rights 2007 (15(1)) 5-23.

Goodman, D., "Analysis of the First Session of the Committee on the Rights of the Child", Netherlands Quarterly for Human Rights, 1995 (1) 43-62.

Hanson, K. and Lundy, L., "Does Exactly What it Says on the Tin? A Critical Analysis and Alternative Conceptualisation of the So-called 'General Principles' of the Convention on the Rights of the Child", The International Journal of Children's Rights 2017 (25(2)), 285-306. DoI:10.1163/15718182-02502011.

O'Neill, O., "Children's Rights and Children's Lives", International Journal of Law and the Family 1992 (6(1)), 24-42, reprint of O'Neill, O., “Children's Rights and Children's Live", Ethics 1988 (98(4)), 445-63.

Tobin, J., “Justifying Children's Rights", International Journal of Children's Rights 2013 (21(3)), 395-441. DOI: 10.1163/15718182-02103004.

Tobin, J., “ Judging the Judges: Are they Adopting the Rights Approach in Matters Involving Children? ", Melbourne University Law Review 2009 (33) 579.

Tobin, J., “Understanding Children's Rights: A Vision beyond Vulnerability", Nordic Journal of International Law 2015 (28) 155-182. DOI: 10.1163/15718107-08402002.

\section{International Materials}

Geneva Declaration of the Rights of the Child, adopted 26 September 1924, League of Nations.

Declaration of the Rights of the Child, UNGA Resolution 1386(XIV) of 20 November 1959.

United Nations Universal Declaration of Human Rights, 10 December 1948, UNGA Resolution $217 \mathrm{~A}$. 
United Nations International Covenant on Economic, Social and Cultural Rights, adopted 16 December 1966, entered into force 3 January 1976.

United Nations International Covenant on Civil and Political Rights, adopted 16 December 1966, entered into force 23 March 1976, 999 U.N.T.S. 171.

Declaration on the Elimination of All Forms of Intolerance and Discrimination Based on Religion or Belief, UNGA Resolution 36/55, A/36/684 (1981).

United Nations Convention on the Rights of the Child, adopted 20 November 1989, entered into force 2 September 1990, 1577 U.N.T.S. 3.

\section{UN Working Group Session Reports on the drafting on the UNCRC}

United Nations Commission on Human Rights, "Report of the Working Group on a draft convention on the rights of the child” (1984), E/CN.4/1984/71.

United Nations Commission on Human Rights, "Report of the Working Group on a draft convention on the rights of the child" (1987), E/CN.4/1987/25.

United Nations Commission on Human Rights, "Report of the Working Group on a draft convention on the rights of the child" (1988), E/CN.4/1988/28.

United Nations Commission on Human Rights, "Report of the Working Group on a draft convention on the rights of the child" (1989), E/CN.4/1989/48.

Office of the United Nations High Commissioner for Human Rights, Legislative History of the Convention on the Rights of the Child (New York/Geneva: United Nations, 2007).

\section{General Comments of the cRc Committee}

UN Committee on the Rights of the Child, General Comment No. 1 (2001), Article 29(1): The Aims of Education, 17 April 2001, CRC/GC/2001/1, paras. 1, 9, 12.

UN Committee on the Rights of the Child, General Comment No. 3 (2003), HIV/AIDS and the rights of the child, 17 March 2003, CRC/GC/2993/3, paras. 12, 20, 22, 23, 29, $40(\mathrm{f})$.

UN Committee on the Rights of the Child, General Comment No. 4 (2003), Adolescent health and development in the context of the Convention on the Rights of the Child, 1 July 2003, CRC/GC/2003/4, paras. 1, 7, 9, 12, 16, 33 .

UN Committee on the Rights of the Child, General Comment No. 5 (2003), General measures of implementation of the Convention on the Rights of the Child, 27 November 2003 , CRC/GC/2003/5, para. 69 .

UN Committee on the Rights of the Child, General Comment No. 7 (2005), Implementing child rights in early childhood, 20 September 2006, CRC/C/GC/7/Rev.1, paras. 3 , $13,17,33$.

UN Committee on the Rights of the Child, General Comment No. 8 (2006), The right of the child to protection from corporal punishment and other cruel or degrading 
forms of punishment (arts. 19, 28, para 2; and 27 inter alia), 2 March 2007, CRC/C/ $\mathrm{GC} / 8^{*}$, paras. 13,28 and 47 .

UN Committee on the Rights of the Child, General Comment No. 9 (2006), The rights of children with disabilities, 27 February 2007, CRC/C/GC/9, paras. 32, 68.

UN Committee on the Rights of the Child, General Comment No. 10 (2007), Children's rights in juvenile justice, 25 April 2007, CRC/C/GC/10, para. 16.

UN Committee on the Rights of the Child, General Comment No. 11 (2009), Indigenous children and their rights under the Convention, 12 February 2009, CRC/C/GC/11, para. 46.

UN Committee on the Rights of the Child, General Comment No. 12, the right of the child to be heard (2009), 20 July 2009, CRC/C/GC/12, paras 31, 69, 79, 80, 84, 91, 94, 100, 134(e), 134(g).

UN Committee on the Rights of the Child, General Comment No. 13 (2011), The right of the child to freedom from all forms of violence, 18 April 2011, CRC/C/GC/13, paras. $5,33,59,66,72(\mathrm{a})$.

UN Committee on the Rights of the Child, General Comment No. 14 (2013) on the right of the child to have his or her best interests taken as a primary consideration (art. 3 , para. 1), 29 May 2013, CRC/C/GC/14, paras. 44, 55, 84 and 93.

UN Committee on the Rights of the Child, General Comment No. 15 (2013) on the right of the child to the enjoyment of the highest attainable standard of health (art. 24), 17 April 2013, CRC/C/GC/15, I. Introduction, paras. 21, 22, 31 and 78.

UN Committee on the Rights of the Child, General Comment No. 16 (2013) on State obligations regarding the impact of the business sector on children's rights, 17 April 2013, CRC/C/GC/16, paras. 23 and 31.

UN Committee on the Rights of the Child, General Comment No. 17 (2013) on the right of the child to rest, leisure, play, recreational activities, cultural life and the arts (art. 31), 17 April 2013, CRCC/GC/17, paras. 14(a), 18, 32, 34 and 57(b).

UN Committee on the Rights of the Child/UN CEDAW Committee, Joint General Recommendation No. 31 of the Committee on the Elimination of Discrimination against Women/General Comment No. 18 of the Committee on the Rights of the Child on Harmful Practices, 14 November 2014, CEDAW/C/GC/31 - CRC/C/GC/18, para. 20.

UN Committee on the Rights of the Child, General Comment No. 20 (2016) on the implementation of the rights of the child during adolescence, 6 December 2016, CRC/C/GC/20, paras. 1, 7(c), 18, 20, 22, 37(e), 39, 40, 42, 43, 46, 50.

UN Committee on the Rights of the Child, General Comment No. 21 (2017) on children in street situations, 21 June 2017, CRC/C/GC/21, paras. 11(b), 15, 33, 35.

Joint general comment No. 3 (2017) of the Committee on the Protection of the Rights of All Migrant Workers and Members of Their Families and No. 22 (2017) of the Committee on the Rights of the Child on the general principles regarding the 
human rights of children in the context of international migration, 16 November 2017, $\mathrm{CmW} / \mathrm{C} / \mathrm{GC} / 3^{-\mathrm{CRC}} / \mathrm{C} / \mathrm{GC} / 22^{*}$, para. 34 .

\section{Other Materials from the CRC Committee}

UN Committee on the Rights of the Child, "Rules of Procedure", 18 March 2015, CRC/C/ Rev.4.

UN Committee on the Rights of the Child, "Twentieth anniversary of the Convention on the Rights of the Child: Dignity, Development and Dialogue", Outline of 2oth Anniversary Event, 1 September 2009.

UN Committee on the Rights of the Child and the Office of the High Commissioner for Human Rights, "2oth Anniversary Adoption of the Convention on the Rights of the Child: Draft recommendations as submitted by thematic Working Groups", 8-9 October 2009.

UN Committee on the Rights of the Child, 43rd session, "Day of General Discussion on the Right of the Child to be Heard", 29 September 2006.

UN Committee on the Rights of the Child, "1oth Anniversary Commemorative Meeting” (30 September-1 October 1999), CRC/C/87, Annex IV. 